\title{
Alleviation of Zea mays L. Nickel Toxicity by Triacontanol Foliar Spray
}

\author{
A. A. Younis ${ }^{1}$, H. A. Ismail ${ }^{1}$ \\ ${ }^{1}$ Botany Department, Faculty of Science, Ain Shams University, Cairo, Egypt.
}

\begin{tabular}{l} 
A R T I C L I N F O \\
\hline Received 03 December 2021 \\
Accepted 16 January 2022 \\
\hline Keywords \\
Nickel Toxicity, \\
Triacontanol, \\
Photosynthesis, \\
Nutrients uptake, \\
Phytohormones. \\
Correspondence \\
H. A. Ismail \\
E-mail
\end{tabular}

hebatollahi@sci.asu.edu.eg

\begin{abstract}
Nickel toxicity is a crucial ecological issue as it affects most soils utilized for crop cultivation. This work aimed to evaluate the effect of triacontanol (TRIA) foliar spray on photosynthesis, and physiological responses of maize (Zea mays L.) seedling under nickel stress. Ten-day-old maize seedlings grown in pots were divided into: (1) control untreated seedlings (irrigated with full nutrient solution), (2) seedlings treated with $\mathrm{NiCl}_{2} .6 \mathrm{H}_{2} \mathrm{O}(100 \mu \mathrm{M})$, (3) Ni-treated seedlings $(100 \mu \mathrm{M})$ sprayed with $25 \mu \mathrm{M}$ TRIA, (4) Ni-treated seedlings $(100 \mu \mathrm{M})$ sprayed with $50 \mu \mathrm{M}$ TRIA. Ni treatment reduced the growth of the 21-day-old seedlings, photosynthetic performance index ( $\mathrm{Pl}_{\text {abs }}$ ) and the contents of photosynthetic pigments, total soluble sugars (TSS), essential elements in roots, relative water content (RWC), as well as the levels of auxins and salicylic acid (SA). Nevertheless, it increased the electrolyte leakage (EL), $\mathrm{Ni}^{2+}$ uptake, plant $\mathrm{Ni}$ transfer rate (Nitransfer rate), root transfer rate factor ( $\left(\mathrm{FF}_{\mathrm{root}}\right)$, and the contents of gibberellic acid $\left(\mathrm{GA}_{3}\right)$ and abscisic acid (ABA). Both Rubisco small subunit (ZmRBCS) and abscisic acid- stress- ripening (ZmASR1) genes were up-regulated under $\mathrm{Ni}$ stress. TRIA foliar spray (with a preference for $50 \mu \mathrm{M}$ ) significantly improved growth attributes, $\mathrm{Pl}_{\text {abs, }}$ pigments content, proline content of shoots, the contents of $\mathrm{K}^{+}, \mathrm{Mg}^{2+}$ and $\mathrm{Ca}^{2+}$, and the expression of both $Z m R B C S$ and ZmASR1 genes of Ni-stressed plants. TRIA also reduced membrane damage expressed as EL, $\mathrm{Ni}_{\text {plant }}$ uptake, and $\mathrm{TF}_{\text {root }}$ and hence alleviated the toxic effects of $\mathrm{Ni}$ stress. TRIA modulated the hormonal balance under Ni stress, particularly SA and auxins.
\end{abstract}

\section{Introduction}

Heavy metal stress (HMs) has become one of the major concerns affecting plant growth and crop productivity for the last couple of decades. Nickel (Ni) pollution is a major environmental issue in the Egyptian soils and waters ${ }^{[1,2]}$, as its concentration is increasing day by day in the environment due to industrialization and anthropic activities ${ }^{[3]}$. Though $\mathrm{Ni}$ is an essential microelement required for proper plant growth and enzyme activity, excess $\mathrm{Ni}$ limits crop productivity and inhibits seed germination and seedling growth ${ }^{[4,5]}$. Moreover, $\mathrm{Ni}$ disrupts different physiological processes like photosynthesis, nutrient uptake, plant water relations, and membrane permeability $[6,7]$, besides it induces osmolytes accumulation like proline ${ }^{[8,9]}$. Under the pressure of the world's increasing population, the negative impacts of $\mathrm{Ni}$ stress on plant growth and yield offer further constraints on global food crop production. Therefore, there is a dire need to develop eco-friendly applicable treatments to increase crop resistance and yield under the existing polluted environment.

Maize (Zea mays L.) is one of the main cereals cultivated globally, coming with the highest consumption for purposes of food, feed, and other uses ${ }^{[10]}$. Besides the harmful effect of planting maize 
in heavy metal polluted soils on its productivity and grain quality, it has hazardous effects on human health as a final consumer ${ }^{[11]}$.

Numerous protectant compounds of diverse functions were found to relieve toxic effects of HMs, such as osmolytes, plant growth hormones, low molecular mass signaling molecules, and trace elements [12]. Triacontanol (TRIA) has been identified as one of the most potent eco-friendly health-safe biostimulant growth regulators ${ }^{[13,14]}$. TRIA is a natural long-chain (C- 30) primary alcohol present in epicuticular waxes of plant leaves ${ }^{[13,15]}$. TRIA was reported to stimulate plant growth and increase stress resistance against a variety of stresses like salinity, drought, and HMs ${ }^{[16-18]}$. Exogenous application of TRIA to plants under abiotic stresses has been shown to prevent oxidative stress, reduce lipid peroxidation of membranes, and regulate genes involved in the modulation of various physiological and biochemical functions, especially stress-related ones ${ }^{[16]}$. TRIA was also recorded to improve the nutrient uptake, photosynthetic pigments, as well as osmolyte accumulation in response to abiotic stresses $[19,20]$. Most studies conducted on alleviating HMs by exogenous application of TRIA focused on photosynthesis and antioxidant defense, but little is known about how TRIA influences mineral nutrition, hormonal balance, and HM absorption and distribution. Therefore, the current study aims to elucidate whether TRIA performs its ameliorative effect on Ni toxicity via enhanced photosynthesis only, or hormonal balance and osmolyte accumulation are involved as well. Another objective is to investigate how TRIA influences the absorption and distribution of both inorganic nutrients and $\mathrm{Ni}$ in different parts of maize seedlings under $\mathrm{Ni}$ stress.

\section{Materials ad Methods}

\subsection{Plant material and growth conditions}

A homogenous lot of viable maize (Zea mays L.) grains (hybrid three-way cross 321) was obtained from the Agricultural Research Centre, Giza, Egypt, and kept in the dark at $4{ }^{\circ} \mathrm{C}$. The grains were surface sterilized by $10 \%$ sodium hypochlorite $(\mathrm{NaClO})$ solution for 5-10 min, then washed thoroughly with distilled water. The grains were then cultivated in sand-containing plastic pots (diameter $15 \mathrm{~cm}$ and height $30 \mathrm{~cm}$ ).
The sand was rinsed with distilled water and then dried in an oven $\left(70{ }^{\circ} \mathrm{C}\right.$ for $48 \mathrm{~h}$, then $200{ }^{\circ} \mathrm{C}$ for $2 \mathrm{~h}$ ) before being used. Plants were grown under natural environmental conditions (14-h photoperiod, light/dark temperature $27 / 15{ }^{\circ} \mathrm{C}$, and relative humidity $60-70 \%$ ). During the first five days of sowing, all seedlings were irrigated with distilled water, then they were irrigated with a full nutrient solution for another 5 days ${ }^{[21]}$. On the tenth day, maize seedlings were divided into four groups: (1) control untreated seedlings, where they were irrigated with the nutrient solution ${ }^{[21]},(2) \mathrm{Ni}-$ stressed seedlings, which were irrigated with the full nutrient solution ${ }^{[21]}$ with $100 \mu \mathrm{M} \mathrm{Ni}\left(\mathrm{NiCl}_{2} .6 \quad \mathrm{H}_{2} \mathrm{O}\right)$ added, and (3\& 4) Ni-stressed seedlings treated with TRIA ( 25 or $50 \mu \mathrm{M}$, respectively), as $\mathrm{Ni}$ was added to the nutrient solution and one of the two concentrations of TRIA ( 25 and $50 \mu \mathrm{M})$ was applied separately as a foliar spray treatment twice (at the first and fifth days of $\mathrm{Ni}$ treatment). The irrigation was conducted at a rate of $50 \mathrm{~mL}$ per pot, three times a week over eleven days of treatments. For each treatment, three independent biological replications were conducted (10 plants each). After harvest, five plants per treatment were taken to measure the growth criteria. Plant leaves were randomly selected from each treatment to measure pigments content, relative water content (RWC), and electrolyte leakage (EL). The remaining seedlings were immediately uprooted, separated, frozen in liquid nitrogen, and stored at $-80^{\circ} \mathrm{C}$ for other analyses.

\subsection{Determination of growth criteria, toxicity level,} and shoot, root, and heavy metal tolerance indices

By the end of the experiment, fresh biomass, shoot and root dry weights (DW) (g per seedling), plant height $(\mathrm{cm})$, and leaf area $\left(\mathrm{cm}^{2}\right)$ of the seedlings were determined. The root/shoot height ratio was calculated by dividing the length of the root by the length of the shoot of the fresh seedling. The toxicity level (\%) of roots was calculated using the method of Valivand et al. ${ }^{[22]}$ by the following formula:

Toxicity level $(\%)=($ Root length of control - Root length of treatment/Root length of control) $\times 100$.

The shoot tolerance index (STI) was calculated according to Alam et al. ${ }^{[23]}$ by the following formulae: STI $(\%)=$ Shoot length of $\mathrm{Ni}$ treated plants /Shoot length of control plants $\times 100$. 
The root tolerance index (RTI) was calculated using the method of Amooaghaie et al. ${ }^{[24]}$ by the following formulae:

RTI $(\%)=$ Root length of $\mathrm{Ni}$ treated plants/ Root length of control plants $\times 100$.

$\mathrm{Ni}$ tolerance index (Ni-TI) was calculated based on Bálint et al. ${ }^{[25]}$ using the formula given below:

$\%(\mathrm{Ni}-\mathrm{TI})=\mathrm{DW}$ of treated plants/DW of control plants $\times 100$.

\subsection{Determination of photosynthetic parameters}

A portable pulse amplitude modulation portable fluorometer (Handy PEA, Hansatech, Norfolk, UK) was used to measure the photosynthetic performance index $\left(\mathrm{Pl}_{\mathrm{abs}}\right)$ of the youngest fully expanded leaves of dark-adapted 21-day-old seedlings ${ }^{[26]}$. Chlorophylls a ( $\mathrm{Chl} \mathrm{a)} \mathrm{and} \mathrm{b} \mathrm{(} \mathrm{Chl} \mathrm{b}$ ), and carotenoids (Car) were extracted in $80 \%(\mathrm{v} / \mathrm{v})$ acetone and measured spectrophotometrically (UNICAM Helios $\alpha$, Unicam, Cambridge, UK) according to Metzner et al. ${ }^{[27]}$. The pigment concentration was calculated and expressed in $\mu \mathrm{g} \mathrm{g}^{-1} \mathrm{DW}$.

\subsection{RNA Extraction and quantitative RT-PCR analysis}

Total RNA was extracted from $30 \mathrm{mg}$ of fresh leaves of each treatment using Gene JET ${ }^{\mathrm{TM}}$ RNA purification Kit (Thermo Fisher Scientific, MA, USA). One $\mu \mathrm{g}$ of total RNA was reverse transcribed into CDNA using Revert Aid First Strand cDNA Synthesis Kit (Thermo Fisher Scientific, MA, USA). Ribulose-1,5-biphosphate carboxylase/oxygenase (Rubisco) small subunit (RBCS) and $A B A$ stress and ripening induced protein (ASR) genes were previously searched from NBCl to perform qRT-PCR. Primer sequences for the reactions were ZmRBCS1; D00170 FP: 5'- GATACCCTGCCTCGNITTCA-3'; RP: 5'- CTCCTGCNICTCCTTGTACA-3', and ZmASR1; AF139814.1 FP: 5'- TTCCACCACANIANIGACGA- 3'; RP: 5'-GATCGGATCGGACGGACTAC-3. Zea mays actin (GenBank accession No. J01238; FP: 5'GATGATGCGCCAAGAGCTG $\quad-3^{\prime} ; \quad$ RP:5'GCCTCATCACCTACGTAGGCAT -3) was used as a reference gene to normalize the relative transcription and to minimize different copy numbers of cDNA templates. PCR amplification specificity was verified using melting curve analysis and data were analyzedfrom three independent samples based on the $2^{-\Delta \Delta C t}$ method ${ }^{[28]}$ after normalized to the expression of each actin gene.

\subsection{Determination of relative water content (RWC)}

RWC of plant leaves was measured by the method of Pan et al. ${ }^{[29]}$. Leaves from selected plants were detached and weighed to obtain their fresh weight (fw), and then soaked in distilled water at room temperature for $24 \mathrm{~h}$, weighed to obtain turgid weight (tw). The leaves were then dried in an oven at $80^{\circ} \mathrm{C}$ for $48 \mathrm{~h}$ to have dry weight ( $\mathrm{dw}$ ). The RWC was then calculated using the following formula:

$$
\operatorname{RWC}(\%)=(f w-d w) /(t w-d w) \times 100
$$

\subsection{Determination of electrolyte leakage (EL)}

Membrane damage caused by lipid peroxidation was determined by recording EL as described by Valentovic et al. ${ }^{[30]}$ using HANNA conductivity meter (HI8733). The EL was determined according to the following equation:

$$
E L \%=\left(L_{1} / L_{2}\right) \times 100
$$

Where $L_{1}$ refers to the electric conductivity of the outer de-ionized water where the leaves were soaked for 24 $h$ at $25^{\circ} \mathrm{C}$, and $\mathrm{L}_{2}$ is the electric conductivity of the outer de-ionized water after autoclaving at $120^{\circ} \mathrm{C}$ for 20 minutes.

\subsection{Determination of soluble sugars and proline contents}

Total soluble sugar (TSS) and proline contents were determined using a spectrophotometer (UNICAM Helios $\alpha$, Unicam, Cambridge, UK) according to McCready et al. ${ }^{[31]}$ and Bates et al. ${ }^{[32]}$, respectively.

\subsection{Plant tissues Ni and nutrient elemental analysis}

The separated roots and shoots of maize plants were oven-dried at $75^{\circ} \mathrm{C}$ for $72 \mathrm{~h}$ to have the dry weight. The uptake of $\mathrm{Ni}$ and elemental nutrients were quantified in the dry samples. The Ni uptake $[\mathrm{Ni}]_{\text {uptake }}\left(\mu \mathrm{g} \mathrm{g}^{-1}\right)$ of maize plant was calculated according to the method of Xiong et al. ${ }^{[33]}$ from the concentrations of the element in roots, shoots, and DW of the respective plant part by using equation no.1:

$[\mathrm{Ni}]_{\text {uptake }}=[\mathrm{Ni}]_{\text {roots }} * \mathrm{DW}_{\text {roots }}+[\mathrm{Ni}]_{\text {shoots }} *$ $\mathrm{DW}_{\text {shoots }} / \mathrm{DW}_{\text {roots }}+\mathrm{DW}_{\text {shoots }}$

The Ni transfer rate ( $\mu \mathrm{g} \mathrm{day}^{-1}$ ) was calculated according to Xiong et al. ${ }^{[33]}$, by dividing $\mathrm{Ni}$ accumulation dose in plants on the exposure duration (11 days) as shown in equation no. 2:

$\mathrm{Ni}$ transfer rate time
(days)
(2) 
Root transfer factor ( $\mathrm{TF}_{\text {root }}$ ) indicates $\mathrm{Ni}$ translocation from exposure medium (soil) to roots of plants. Similarly, the shoot transfer factor $\left(\mathrm{TF}_{\text {shoot }}\right)$ denotes $\mathrm{Ni}$ translocation from the roots to the shoots. These transfer factors were estimated using equations 3 and 4 according to Abbas et al. ${ }^{[34]}$ and Xiong et al. ${ }^{[33]}$, respectively:

$\mathrm{TF}_{\text {root }}=[\mathrm{Ni}]_{\text {roots }} /[\mathrm{Ni}]_{\text {exposure medium }}$

$\mathrm{TF}_{\text {shoot }}=[\mathrm{Ni}]_{\text {shoots }} /[\mathrm{Ni}]_{\text {roots }}$

Where, $[\mathrm{Ni}]_{\text {roots, }}[\mathrm{Ni}]_{\text {shoots, }}$ and $[\mathrm{Ni}]_{\text {exposure medium }}$ are the concentrations of $\mathrm{Ni}$ in maize roots, shoots, and soil, respectively. $\mathrm{DW}_{\text {roots }}$ is the dry weight of roots, and $\mathrm{DW}_{\text {shoots }}$ is the shoot dry weight. The concentration of macro- $\left(\mathrm{K}^{+}, \mathrm{Ca}^{2+}, \mathrm{Mg}^{2+}\right)$ and micro-nutrients $\left(\mathrm{Fe}^{3+}, \mathrm{Zn}^{2+}\right.$, $\mathrm{Mn}^{2+}$ ) were determined by atomic absorption spectroscopy (Savant AA, GBC, Australia), and the results were expressed as mg of the metal per $\mathrm{Kg} \mathrm{DW}$ of the sample.

\subsection{Determination of endogenous phytohormones}

Plant phytohormones were extracted using freshly collected samples. The quantity of each hormone was determined using high performance liquid chromatography (Agilent 1260 Infinity HPLC Series (Agilent $^{\circledR}$, USA), equipped with Quaternary pump, a Zorbax Eclipse Plus C18 column (100 mm x $4.6 \mathrm{~mm}$ i.d., (Agilent ${ }^{\circledR}$, USA)) operated at $35^{\circ} \mathrm{C}$. The separation was achieved using gradient elution with (A) $5 \mathrm{mM}$ Ammonium acetate/ $0.05 \%$ formic acid in water, (B) Acetonitrile. The injected volume was $20 \mu \mathrm{L}$ for detection, a Variable Wavelength Detector was set at $254 \mathrm{~nm}$. The concentrations of indole acetic acid (IAA), indole butyric acid (IBA), abscisic acid ( $A B A)$, gibberellic acid $\left(G A_{3}\right)$, and salicylic acid (SA) in the samples were assayed against internal standards.

\subsection{Statistical analysis}

Analysis of variance (ANOVA) and Pearson's correlation analyses of the data were performed using SPSS v. 20.0 (SPSS, ChicNio, USA) software. The means were compared to calculate the statistical significance by Duncan's test at $P \leq 0.05$.

\section{RESULTS}

\subsection{Growth, toxicity level, and Ni tolerance indices}

Exposure of maize seedlings to $\mathrm{Ni}$ stress reduced its growth significantly in terms of plant height, fresh biomass, leaf area, root/shoot length ratio, and shoot dry weight as compared withtheir controls Fig. 1 \& 2 . TRIA treatment $(25 \mu \mathrm{M})$ significantly enhanced the plant height, fresh biomass, leaf area, and shoot dry weight under $\mathrm{Ni}$ stress and restored its growth to the level of the control untreated seedlings Fig. $1 \mathrm{a}, \mathrm{b}$ \&c \& Fig. 2a. Though a significant enhancement in the root/shoot length ratio was observed when both concentrations of TRIA ( 25 and $50 \mu \mathrm{M}$ ) were applied to $\mathrm{Ni}$-stressed seedlings, yet it failed to restore its value to comparable levels of the control Fig. 1d. The toxicity level in roots of $\mathrm{Ni}$-stressed plants reached about $40.1 \%$ higher than unstressed controls, while this toxicity decreased by $36.4 \%$ and $60 \%$ at 25 and $50 \mu \mathrm{M}$ TRIA treatments, respectively Fig. 1e. In response to $\mathrm{Ni}$ stress, a significant decrease was recorded in $\mathrm{Ni}$ tolerance index ( $\mathrm{Ni}-\mathrm{TI})$, shoot tolerance index (STI), and root tolerance index (RTI) percentages to 70\%, $59.9 \%$, and $91.9 \%$ of the values of the control maize plants, respectively, Fig. 1 \& \& Fig. 2 b. However, treatment of $\mathrm{Ni}$-stressed seedlings with TRIA $(25 \mu \mathrm{M})$ significantly restored both $\mathrm{Ni}-\mathrm{TI} \mathrm{RTI}$ percentages to the control level Fig. If \& Fig. $2 b$. The results showed that treatment with $50 \mu \mathrm{M}$ TRIA was more efficient in reducing $\mathrm{Ni}$ toxicity and enhancing shoot and root tolerance indices and growth of maize seedlings under stress.

\subsection{Photosynthetic traits}

Ni-stressed plants showed significant lower carotenoids and total pigments contents, relative to the controls Fig. 3a. Ni-Stressed plants treated with both concentrations of TRIA contained a significant amount of $\mathrm{Chl} \mathrm{a,} \mathrm{Chl} \mathrm{b,} \mathrm{Car} \mathrm{and} \mathrm{total} \mathrm{pigments} \mathrm{contents}$ (in a concentration-dependent pattern) that exceeded its corresponding levels not only in Ni-stressed plants but also in control plants Fig. 3a. For instance, Nistressed plants treated by $50 \mu \mathrm{M}$ TRIA accumulated about $8,4.5,1.6$, and 4.5 folds of $\mathrm{Chl} \mathrm{a,} \mathrm{Chl} \mathrm{b,} \mathrm{Car,} \mathrm{and}$ total pigments higher than the control untreated plants, respectively Fig. 3a. Ni-stressed plants exhibited about half the value of $\mathrm{Pl}_{\mathrm{abs}}$ recorded in the controls, whereas treatment with 25 and $50 \mu \mathrm{M}$ TRIA resulted in higher $\mathrm{Pl}_{a b s}$ by $61.86 \%$ and $89.83 \%$, respectively than the Ni-stressed plants' values Fig. 3b, to reach comparable levels to the control. The expression of $Z m R B C S 1$ was up-regulated in response to $\mathrm{Ni}$ stress by $21.4 \%$ higher than the controls Fig. $3 \mathrm{c}$, with further increase in the expression levels of rubisco 
small subunit gene (ZmRBCS1) by $5.5 \%$ in $50 \mu \mathrm{M}$ TRIA treated plants, while a decrease by $6.6 \%$ in its expression was recognized in the plant that received 25 $\mu \mathrm{M}$ TRIA Fig. 3c.
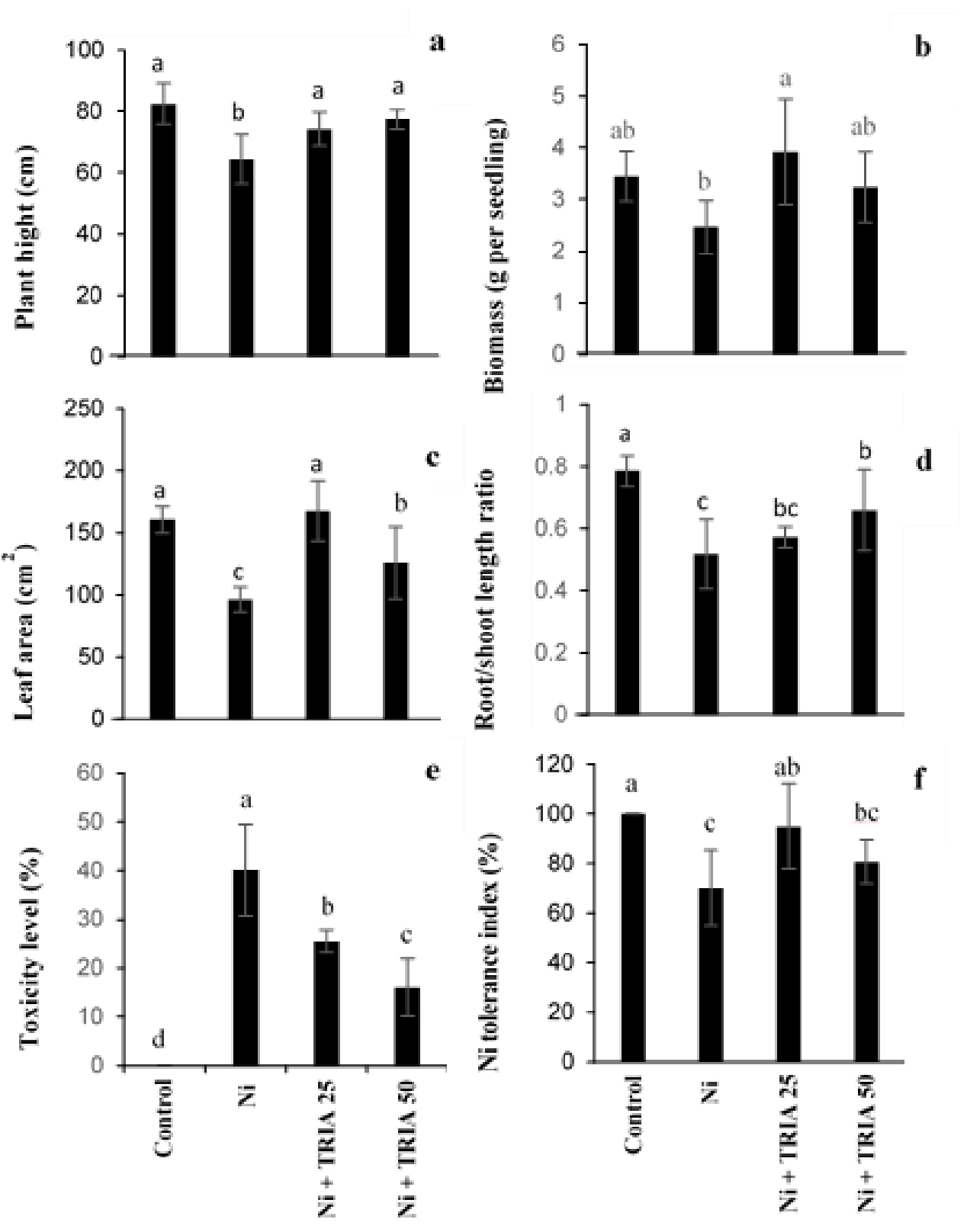

Fig. 1. Effect of nickel (Ni) alone or combined with different concentrations of triacontanol (TRIA; 25 and $50 \mu \mathrm{M}$ ) on a) plant height, b) plant fresh biomass c) leaf area, d) root/shoot length ratio, e) the percentage of Ni toxicity, and $\mathbf{f}$ ) the percentage of Ni tolerance index as compared with the control untreated maize seedling. Data are means $\pm S D(n=5)$, bars with different letters are significantly different at $P \leq 0.05$ 


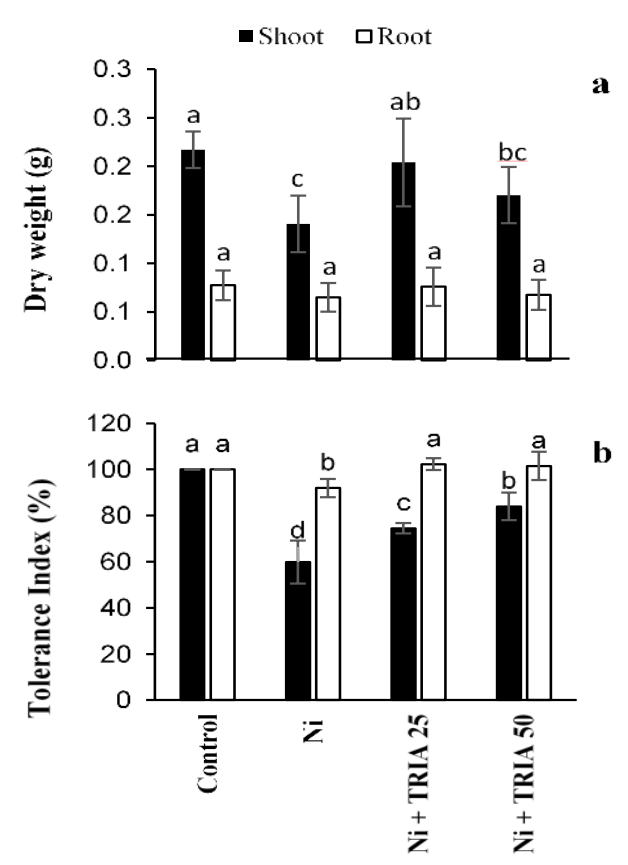

Fig. 2. Effect of Nickel ( $\mathrm{Ni}$ ) alone or combined with different concentrations of triacontanol (TRIA; 25 and $50 \mu \mathrm{M}$ ) on a) shoot and root dry weights, and b) percentage of the shoot and root Ni tolerance indices as compared with the control untreated maize seedling. Data are means $\pm S D(n=5)$, bars with different letters are significantly different at $P \leq 0.05$
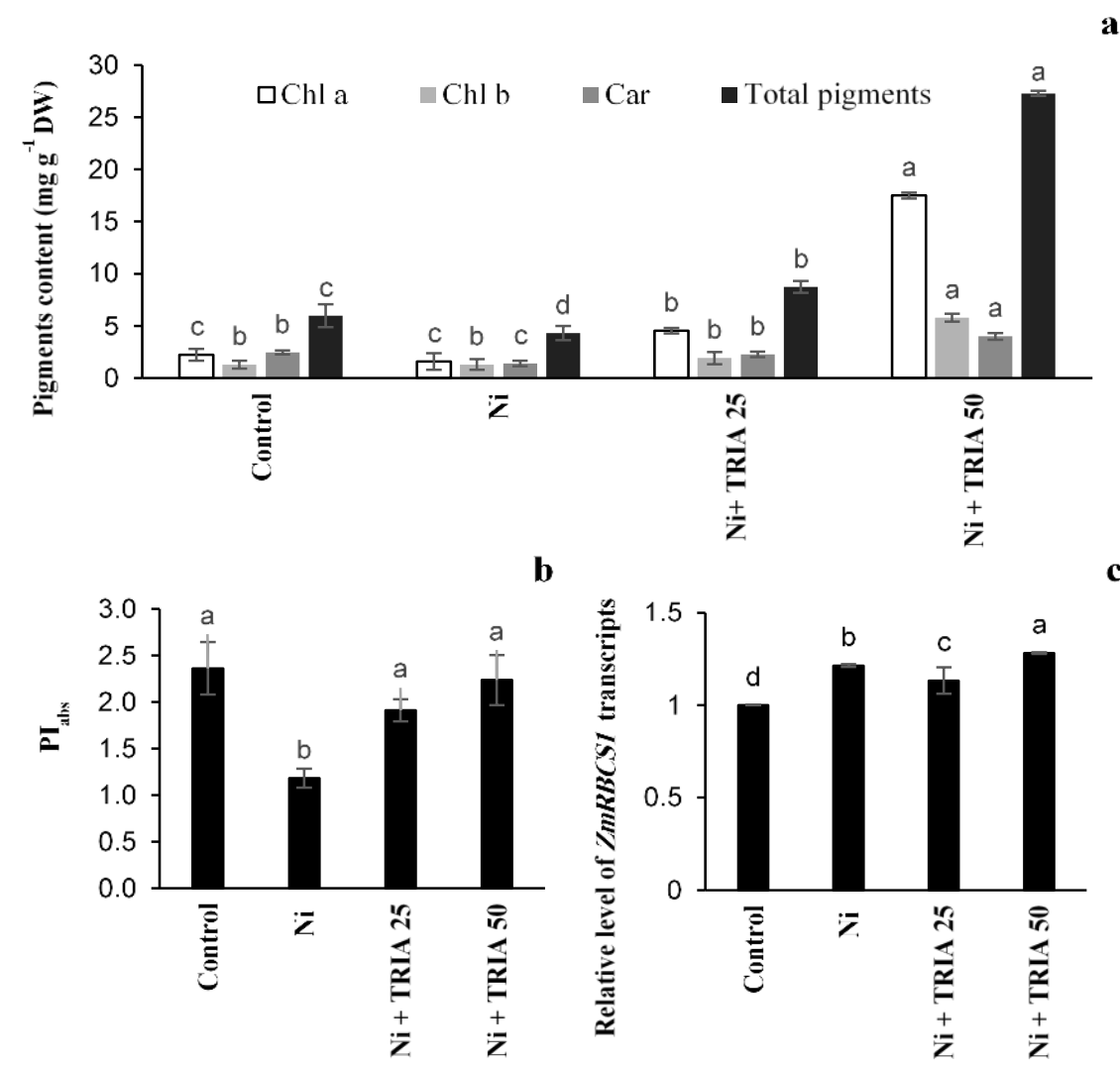

Fig. 3. Effect of nickel ( $\mathrm{Ni}$ ) alone or combined with different concentrations of triacontanol (TRIA; 25 and 50 $\mu \mathrm{M}$ ) on a) pigments content (mg g-1 DW), b) photosynthetic performance index (Plabs), and c) ZmRBCS1 (Rubisco small subunit gene) expression of maize leaves. Data are means $\pm S D, n=3$, bars with different letters indicate significant differences at $P \leq 0.05$ 
3.3 Relative water content (RWC), the electrolyte leakage

(EL), total soluble sugar (TSS), and proline contents

$\mathrm{Ni}$ treatment reduced the RWC of both shoot and root by $7.72 \%$ and $31.9 \%$, respectively, relative to the controls, while TRIA application to the stressed seedlings had no mitigated impact on the declined RWC, except for TRIA ( $25 \mu \mathrm{M})$ on shoot RWC Fig. $4 a$. The EL increased in shoots and roots of $\mathrm{Ni}$-stressed plants as compared with the controls, while TRIA treatments counteracted the injurious impact of $\mathrm{Ni}$ on the EL level in both the shoots and roots, as EL\% was restored to control level in $\mathrm{Ni}$-stressed maize shoots treated with $50 \mu \mathrm{M}$ TRIA Fig. 4a.

$\mathrm{Ni}$ treatment did not have any significant effect on the proline content of both shoot and root as compared to the control untreated sample, whereas both TRIA treatments resulted in a significant decrease in the proline content of the roots. In shoots, the highest proline content was measured in $\mathrm{Ni}$-stressed seedlings treated with $50 \mu \mathrm{M}$ TRIA, which was $151 \%$ and $136 \%$ higher than the proline contents of $\mathrm{Ni}$ stressed and control shoots, respectively. $\mathrm{Ni}$-stressed seedlings treated with $25 \mu \mathrm{M}$ TRIA accumulated the lowest concentrations of proline, as it was about half the value recorded in those treated with $50 \mu \mathrm{M}$ TRIA Fig. 3c \& 4c.

No significant difference was observed between the TSS contents of roots of all plants under different treatments Fig. 4d. The highest TSS content was measured in the shoot of control plants, which was decreased significantly under Ni stress by $16 \%$. The TSS level of shoots fell dramatically (half its value in the $\mathrm{Ni}$ stressed seedlings) upon TRIA treatment combined with Ni stress Fig. $4 \mathrm{~d}$.
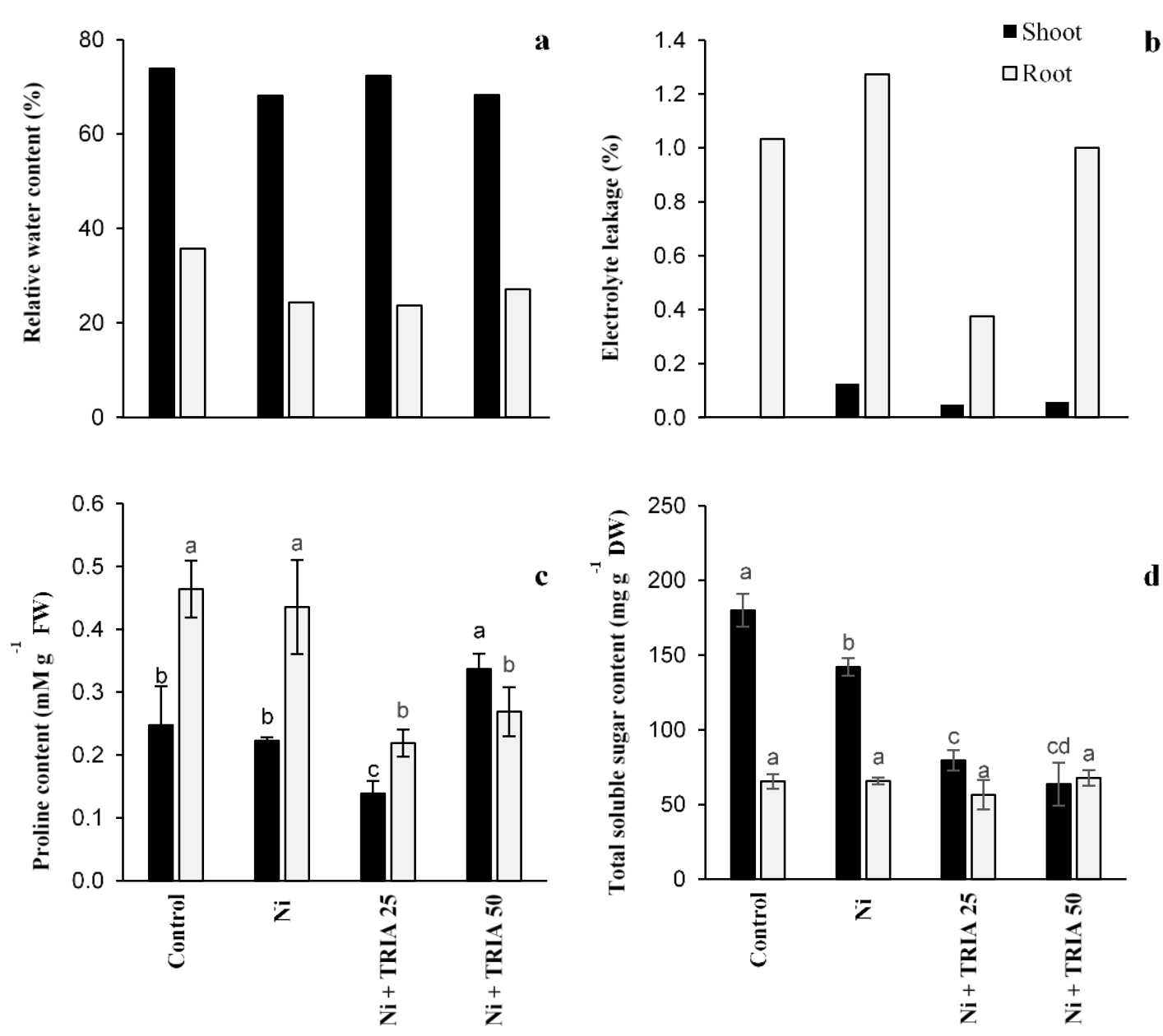

Fig. 4. Effect of nickel (Ni) alone or combined with different concentrations of triacontanol (TRIA; 25 and 50 $\mu \mathrm{M})$ on a) relative water content (RWC), b) electrolyte leakage (EL), c) proline content, and d) total soluble sugar content of maize seedlings. Data with statistical analysis are means $\pm S D, n=3$, bars with different letters indicate significant differences at $P \leq 0.05$ 
3.4 Ni uptake, transfer rate, and translocation factor of $\mathrm{Ni}$ in shoots and roots

The Ni-treated maize seedlings recorded the greatest $\mathrm{Ni}_{\text {plant }}$ uptake and transfer rates ( $\mathrm{Ni}_{\text {transfer rate }}$ ) by $27.3 \%$ and $35.7 \%$ more than the controls, respectively. NiStressed plants showed the highest root transfer factor ( TF $\left._{\text {root }}\right)$ and the lowest Shoot transfer factor ( $T F_{\text {shoot }}$ ), while control plants manifested the maximum $\mathrm{TF}_{\text {shoot }}$ and the minimum TFroot. As the concentration of TRIA treatment to $\mathrm{Ni}$-stressed seedlings increased, $\mathrm{TF}_{\text {shoot }}$ increased and $\mathrm{TF}_{\text {root }}$ decreased Table 1. A negative strong correlation was observed between $\mathrm{TF}_{\text {shoot }}$ and $T F_{\text {root }}\left(R^{2}=0.99\right)$ Table 3.

\subsection{Plant nutrients uptake}

Under Ni stress, $\mathrm{K}^{+}, \mathrm{Mg}^{2+}, \mathrm{Ca}^{2+}, \mathrm{Zn}^{2+}, \mathrm{Mn}^{2+}$ and $\mathrm{Fe}^{2+}$ levels in the root tissues were reduced as compared with their corresponding in the controls Table 2. Shoots showed an obvious accumulation of $\mathrm{K}^{+}, \mathrm{Mg}^{2+}$, $\mathrm{Ca}^{2+}$, and $\mathrm{Zn}^{2+}$ contents under Ni stress, while $\mathrm{Mn}^{2+}$ and $\mathrm{Fe}^{2+}$ contents were reduced compared to the controls Table 2. $\mathrm{Ca}^{2+}$ and $\mathrm{Zn}^{2+}$ were the only elements thataccumulated in whole $\mathrm{Ni}$-stressed seedlings more than the control, while the other ions were decreased. Roots of Ni-stressed seedlings treated with TRIA (25 $\mu \mathrm{M})$ accumulated higher $\mathrm{K}^{+}, \mathrm{Mg}^{2+}$, and $\mathrm{Ca}^{2+}$ in the roots by $58.6 \%, 94.7 \%$, and $60.5 \%$ than $\mathrm{Ni}$ - stressed roots, and those treated with TRIA $50 \mu \mathrm{M}$ accumulated the same ions by $67.2 \%, 121 \%$, and $75 \%$, respectively Table 2. The content of these three ions in the whole plant increased also upon both TRIA treatments under stress Table 2. While treatment with $50 \mu \mathrm{M}$ TRIA reduced $\mathrm{K}^{+}, \mathrm{Mg}^{2+}, \mathrm{Ca}^{2+}$, and $\mathrm{Zn}^{2+}$ contents in the shoots, $25 \mu \mathrm{M}$ TRIA elevated the levels of $\mathrm{K}^{+}, \mathrm{Mn}^{2+}$, and $\mathrm{Fe}^{2+}$ in the shoots under Ni stress Table 2.

\subsection{Endogenous phytohormone profile}

$\mathrm{Ni}$ treatment caused a decline in IAA content in the shoots by $39 \%$, meanwhile, it resulted in $171 \%$ and $118 \%$ increase in its content in the roots and whole seedling, compared with the controls. The levels of IBA decreased and consequently total auxins were decreased in maize shoots and roots under $\mathrm{Ni}$ stress relative to control plants Fig. 5b \& c. A similar trend was observed in SA content Fig. 5e. A four-fold IAA/IBA ratio was observed in Ni-stressed maize roots, higher than the control ones Fig. $5 \mathrm{~d}$. Maize roots and shoots exposed to $\mathrm{Ni}$ showed $\mathrm{GA}_{3}$ contents about five folds higher than that of the controls Fig. 5f. Though no ABA was detected in Ni-stressed maize shoots, a high level was accumulated in the roots Fig. $5 \mathrm{~g}$. Application of 50 $\mu \mathrm{M}$ TRIA to Ni-stressed roots resulted in an increase in the IAA, IAA/IBA ratio, and SA levels by $47.3 \%, 361.1 \%$, and $115 \%$, respectively Fig. $5 a$, d \&e, while it decreased IBA, $\mathrm{GA}_{3}$, and ABA contents by $59 \%, 38 \%$, and $20 \%$, respectively, as compared with the untreated $\mathrm{Ni}$ stressed plants Fig. 5b, f \&g. Ni treatment caused a marked upregulation of ZmASR1 expression in shoots but not in roots, which showed further significant upregulation by TRIA treatments in a concentrationdependent manner Fig. 5h. The expression level in 50 $\mu \mathrm{M}$ TRIA-treated plants reached about 5.6-folds in shoots and roots in comparison with the untreated $\mathrm{Ni}$ stressed seedlings Fig. $5 \mathrm{~h}$.

Table 1 The Plant Ni uptake ( $\mu \mathrm{g} \mathrm{g}^{-1}$ ), Ni transfer rate $\left(\mu \mathrm{g}\right.$ day $\left.{ }^{-1}\right)$, and root and shoot transfer factor (Ni TF) of maize seedlings after 15 days of Nickel ( $\mathrm{Ni}$ ) exposure alone or combined with different concentrations of triacontanol (TRIA; 25 and $50 \mu \mathrm{M}$ )

\begin{tabular}{ccccc}
\hline \multirow{2}{*}{ Treatment } & Plant Ni uptake & Plant Ni transfer rate & \multicolumn{2}{c}{ Ni TF } \\
\cline { 4 - 5 } Control & 0.0022 & 0.00014 & 0.49 & 0.98 \\
$\mathrm{Ni}$ & 0.0028 & 0.00019 & 0.30 & 1.51 \\
$\mathrm{Ni}+$ TRIA 25 & 0.0027 & 0.00018 & 0.35 & 1.43 \\
$\mathrm{Ni}+$ TRIA 50 & 0.0026 & 0.00017 & 0.36 & 1.32 \\
\hline
\end{tabular}


Table 2. Effect of nickel ( $\mathrm{Ni}$ ) alone or combined with different concentrations of triacontanol (TRIA; 25 and $50 \mu \mathrm{M})$ on the macro and micro-nutrient contents of maize root, shoot, and whole seedling tissues

\begin{tabular}{|c|c|c|c|c|c|c|}
\hline \multirow{2}{*}{\multicolumn{2}{|c|}{ Nutrients }} & \multirow{2}{*}{ Organ } & \multicolumn{4}{|c|}{ Treatment } \\
\hline & & & Control & $\mathrm{Ni}$ & $\mathrm{Ni}+$ TRIA 25 & $\mathrm{Ni}+$ TRIA 50 \\
\hline \multirow{15}{*}{ 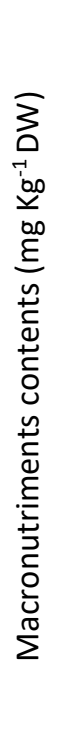 } & \multirow{4}{*}{ K } & Shoot & $47,900.00$ & $49,400.00$ & $52,800.00$ & $43,700.00$ \\
\hline & & Root & $13,400.00$ & $5,800.00$ & $9,200.00$ & $9,700.00$ \\
\hline & & Whole seedling & $61,300.00$ & $55,200.00$ & $62,000.00$ & $53,400.00$ \\
\hline & & Shoot/root ratio & 3.575 & 8.517 & 5.739 & 4.505 \\
\hline & \multirow{4}{*}{$\mathrm{Mg}$} & Shoot & $3,000.00$ & $3,700.00$ & $3,500.00$ & $2,600.00$ \\
\hline & & Root & $2,800.00$ & $1,900.00$ & $3,700.00$ & $4,200.00$ \\
\hline & & Whole seedling & $5,800.00$ & $5,600.00$ & $7,200.00$ & $6,800.00$ \\
\hline & & Shoot/root ratio & 1.071 & 1.947 & 0.946 & 0.619 \\
\hline & \multirow{4}{*}{$\mathrm{Ca}$} & Shoot & $4,100.00$ & $7,100.00$ & $6,100.00$ & $3,600.00$ \\
\hline & & Root & $10,500.00$ & $7,600.00$ & $12,200.00$ & $13,300.00$ \\
\hline & & Whole seedling & $14,600.00$ & $14,700.00$ & $18,300.00$ & $16,900.00$ \\
\hline & & Shoot/root ratio & 0.390 & 0.934 & 0.500 & 0.271 \\
\hline & \multirow{3}{*}{$\begin{array}{c}\mathrm{Ca} / \mathrm{Mg} \\
\text { ratio }\end{array}$} & Shoot & 1.37 & 1.92 & 1.74 & 1.38 \\
\hline & & Root & 3.75 & 4.00 & 3.30 & 3.17 \\
\hline & & Whole seedling & 2.52 & 2.63 & 2.54 & 2.49 \\
\hline \multirow{12}{*}{ 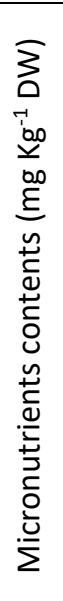 } & \multirow{4}{*}{$\mathrm{Zn}$} & Shoot & 55.57 & 84.67 & 51.19 & 71.47 \\
\hline & & Root & 82.85 & 82.20 & 77.07 & 83.52 \\
\hline & & Whole seedling & 138.42 & 166.87 & 128.26 & 154.99 \\
\hline & & Shoot/root ratio & 0.671 & 1.030 & 0.664 & 0.856 \\
\hline & \multirow{4}{*}{$\mathrm{Mn}$} & Shoot & 78.93 & 62.72 & 70.69 & 55.59 \\
\hline & & Root & 168.60 & 120.97 & 102.76 & 86.30 \\
\hline & & Whole seedling & 247.53 & 183.69 & 173.45 & 141.89 \\
\hline & & Shoot/root ratio & 0.468 & 0.518 & 0.688 & 0.644 \\
\hline & \multirow{4}{*}{$\mathrm{Fe}$} & Shoot & 254.51 & 168.55 & 220.18 & 194.57 \\
\hline & & Root & $1,861.86$ & $1,816.04$ & $2,087.35$ & $1,670.38$ \\
\hline & & Whole seedling & $2,071.37$ & $2,029.59$ & $2,307.53$ & $1,864.95$ \\
\hline & & Shoot/root ratio & 0.140 & 0.091 & 0.105 & 0.116 \\
\hline
\end{tabular}

\subsection{Correlation of traits}

Correlation among morpho-physiological traits Table 3 revealed a highly significant $(P<0.01)$ positive correlation between fresh biomass and all the plant height, leaf area, Ni-TI and shoot DW. Similarly, Ni-TI was also significantly positively correlated with plant height, root/shoot ratio, leaf area, RTI, and shoot DW, while it was significantly negatively correlated with the $\mathrm{Ni}$ toxicity level.
The contents of $\mathrm{Chl} \mathrm{a,} \mathrm{b}$ and carotenoids exhibited a significant strong positive correlation to each other and proline content of the shoots, but they were significantly negatively correlated with the shoot's TSS. The proline content of the shoots and TSS of the roots were significantly positively correlated, whereas proline content of the roots and TSS of the shoots showed a strong significant positive correlation Table 3. 
Table 3. Pearson-Correlation coefficients comparisons for various plant traits under various treatments

\begin{tabular}{|c|c|c|c|c|c|c|c|c|c|c|c|c|c|c|c|c|c|}
\hline & Biomass & $\begin{array}{l}\text { Plant } \\
\text { height }\end{array}$ & $\begin{array}{l}\text { Root } \\
\text { /Shoot }\end{array}$ & Leaf area & $\begin{array}{c}\text { Toxicity } \\
\text { level }\end{array}$ & RTI & STI & $\mathrm{Ni}-\mathrm{Ti}$ & $\begin{array}{c}\text { Shoot } \\
\text { DW }\end{array}$ & Root DW & $\mathrm{Chl} \mathrm{a}$ & $\mathrm{Chl} \mathrm{b}$ & Car & $\begin{array}{c}\text { Shoot } \\
\text { TSS }\end{array}$ & Root TSS & $\begin{array}{l}\text { Shoot } \\
\text { proline }\end{array}$ & $\begin{array}{l}\text { Root } \\
\text { proline }\end{array}$ \\
\hline Biomass & 1 & & & & & & & & & & & & & & & & \\
\hline Plant height & $.604^{* *}$ & 1 & & & & & & & & & & & & & & & \\
\hline Root/shoot & 0.164 & $.748^{* *}$ & 1 & & & & & & & & & & & & & & \\
\hline Leaf area & $.755^{* *}$ & $.605^{* *}$ & 0.347 & 1 & & & & & & & & & & & & & \\
\hline Toxicity level & -0.389 & $-.815^{* *}$ & $-.758^{* *}$ & $-.507^{*}$ & 1 & & & & & & & & & & & & \\
\hline RTI & 0.389 & $.815^{* *}$ & $.758^{* *}$ & $.507^{*}$ & $-1.000^{* *}$ & 1 & & & & & & & & & & & \\
\hline STI & 0.362 & $.529^{*}$ & $.461^{*}$ & 0.419 & -0.442 & 0.442 & 1 & & & & & & & & & & \\
\hline $\mathrm{Ni}-\mathrm{Ti}$ & $.798^{* *}$ & $.742^{* *}$ & $.452^{*}$ & $.793^{* *}$ & $-.643^{* *}$ & $.643^{* *}$ & $.496^{*}$ & 1 & & & & & & & & & \\
\hline Shoot DW & $.871^{* *}$ & $.752^{* *}$ & 0.393 & $.812^{* *}$ & $-.633^{* *}$ & $.633^{* *}$ & 0.335 & $.927^{* *}$ & 1 & & & & & & & & \\
\hline Root DW & 0.432 & 0.369 & 0.350 & 0.352 & -0.294 & 0.294 & $.493^{*}$ & $.566^{* *}$ & 0.359 & 1 & & & & & & & \\
\hline $\mathrm{Chl} \mathrm{a}$ & 0.116 & 0.209 & -0.070 & -0.248 & -0.247 & 0.247 & 0.180 & -0.146 & -0.062 & -0.219 & 1 & & & & & & \\
\hline $\mathrm{Chl} \mathrm{b}$ & 0.112 & 0.303 & 0.037 & -0.230 & -0.311 & 0.311 & 0.347 & -0.069 & -0.039 & -0.175 & $.967^{* *}$ & 1 & & & & & \\
\hline Car & 0.152 & 0.364 & 0.094 & -0.047 & -0.548 & 0.548 & 0.257 & -0.006 & 0.104 & -0.271 & $.916^{* *}$ & $.896^{* *}$ & 1 & & & & \\
\hline Shoot TSS & -0.340 & 0.055 & 0.570 & 0.014 & -0.247 & 0.247 & -0.122 & 0.120 & 0.008 & 0.272 & $-.735^{* *}$ & $-.686^{*}$ & -0.575 & 1 & & & \\
\hline Root TSS & -0.451 & 0.142 & 0.264 & -0.536 & -0.233 & 0.233 & 0.133 & -0.158 & -0.349 & 0.153 & 0.227 & 0.351 & 0.242 & 0.197 & 1 & & \\
\hline Shoot proline & -0.354 & 0.283 & 0.366 & -0.506 & -0.414 & 0.414 & 0.019 & -0.301 & -0.263 & -0.235 & $.669^{*}$ & $.691^{*}$ & $.639^{*}$ & -0.071 & $.644^{*}$ & 1 & \\
\hline Root proline & -0.468 & 0.090 & 0.496 & -0.224 & -0.210 & 0.210 & -0.123 & 0.005 & -0.172 & 0.262 & -0.536 & -0.465 & -0.480 & $.876^{* *}$ & 0.402 & 0.197 & 1 \\
\hline
\end{tabular}

\section{DISCUSSION}

In the present investigation, the growth, Ni-TI, RTI, and STI of maize seedlings were negatively affected by $\mathrm{Ni}$ treatment. Such impacts of $\mathrm{Ni}$ stress were previously reported in different plant species ${ }^{[35,36]}$. It was recorded that roots were more sensitive to Ni stress than shoots [37], which was displayed in this study as reduced root/shoot length ratio and RTI \% under Ni stress. The $\mathrm{Ni}$-induced decline in maize seedling height, biomass, leaf area, and shoot DW might be attributed to retarded mitotic and metabolic activities, inhibition of cell division, and/or elongation, distorted root hairs and suppressed the emergence of new ones, disturbed mineral uptake, and altered water and hormonal balances ${ }^{[38,39]}$. TRIA application to Ni-stressed maize seedlings alleviated the toxic effects of $\mathrm{Ni}$ on the growth attributes, $\mathrm{Ni}-\mathrm{Ti}, \mathrm{RTI}, \mathrm{STI}$, and reduced toxicity of $\mathrm{Ni}$ tested in this work. Similar ameliorating effects of TRIA on plant growth have been also demonstrated by other workers ${ }^{[15,37,38]}$, which is probably due to TRIAmediated activation of $L(+)$-adenosin (a second messenger in the signal transduction mechanism of action of TRIA), which leads to cell enlargement and proliferation ${ }^{[42]}$.

The present results also showed that $\mathrm{Pl}_{\mathrm{abs}}$, Car, and total photosynthetic pigments contents of maize seedlings were greatly reduced by $\mathrm{Ni}$ stress, which was mostly related to pigment degradation and inhibited biosynthesis, obstructed structure and function of chloroplasts, and interrupted electron transport, and reduced leaf area as shown by Younis \& Ismail ${ }^{[43]}$ and Bhalerao et al. ${ }^{[37]}$. Though published works demonstrated the reduced activity of Rubisco under $\mathrm{Ni}$ stress ${ }^{[44]}$, our data indicated that RBCS expression of Rubisco small subunit increased under $\mathrm{Ni}$ stress, perhaps acting as a reparation mechanism to compensate for reduced leaf area and $\mathrm{Pl}_{\mathrm{abs}}$. In the current work, foliar application of TRIA (particularly $50 \mu \mathrm{M}$ ) to $\mathrm{Ni}$ stressed maize seedling resulted in a great leap in the contents of all photosynthetic pigments, $\mathrm{Pl}_{\mathrm{abs}}$, and $R B C S$ expression, which agrees with those of other researchers ${ }^{[13,17]}$. 


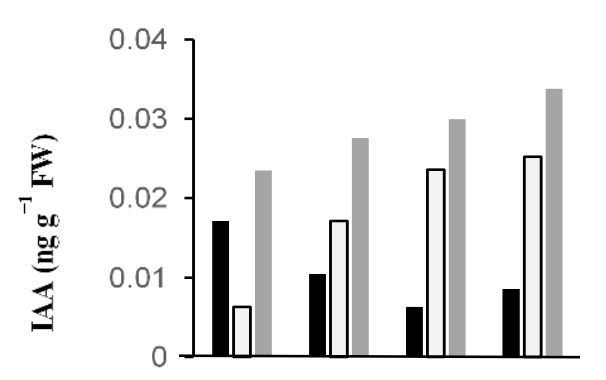

a
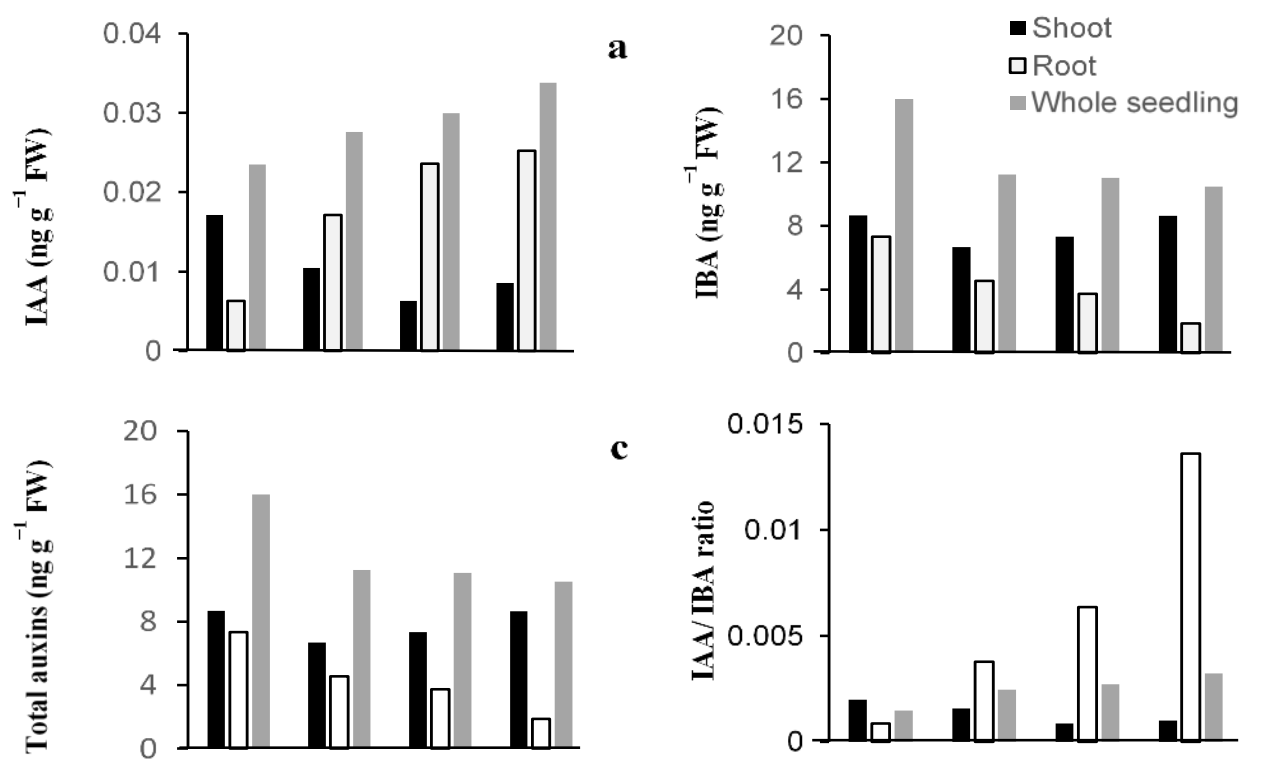

c
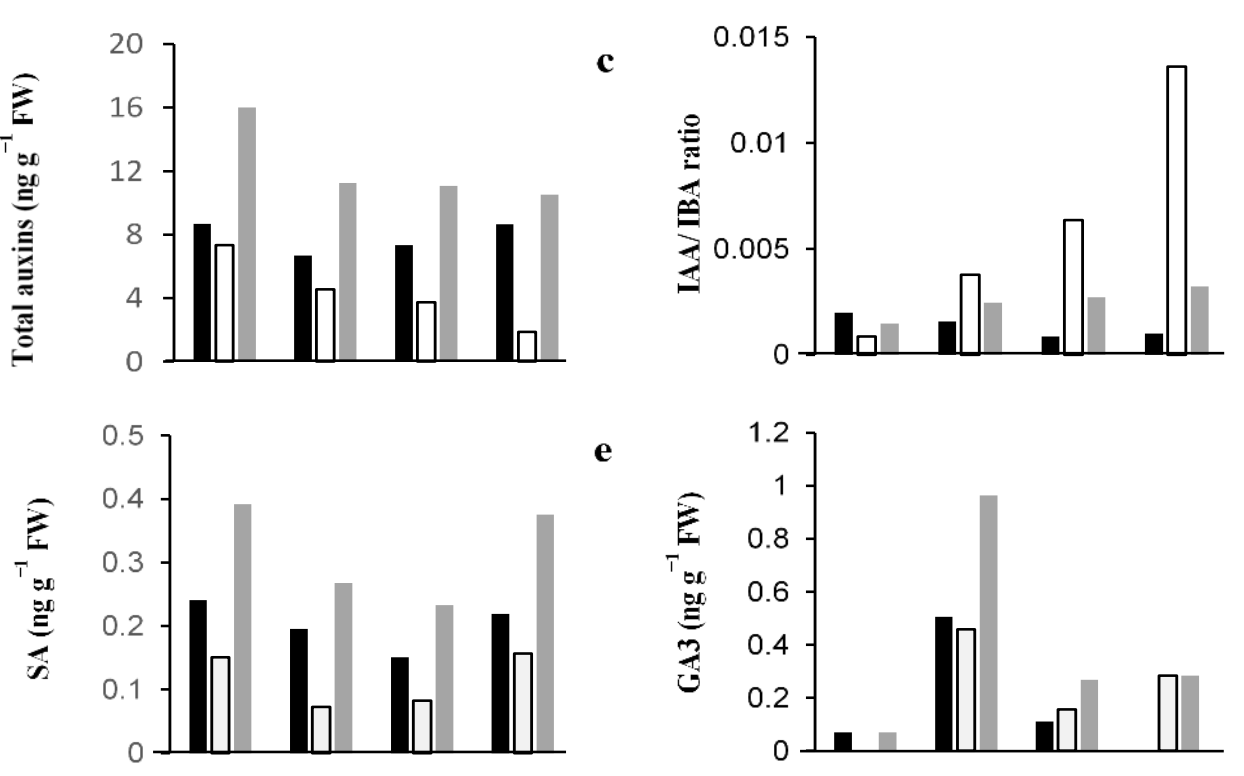

e
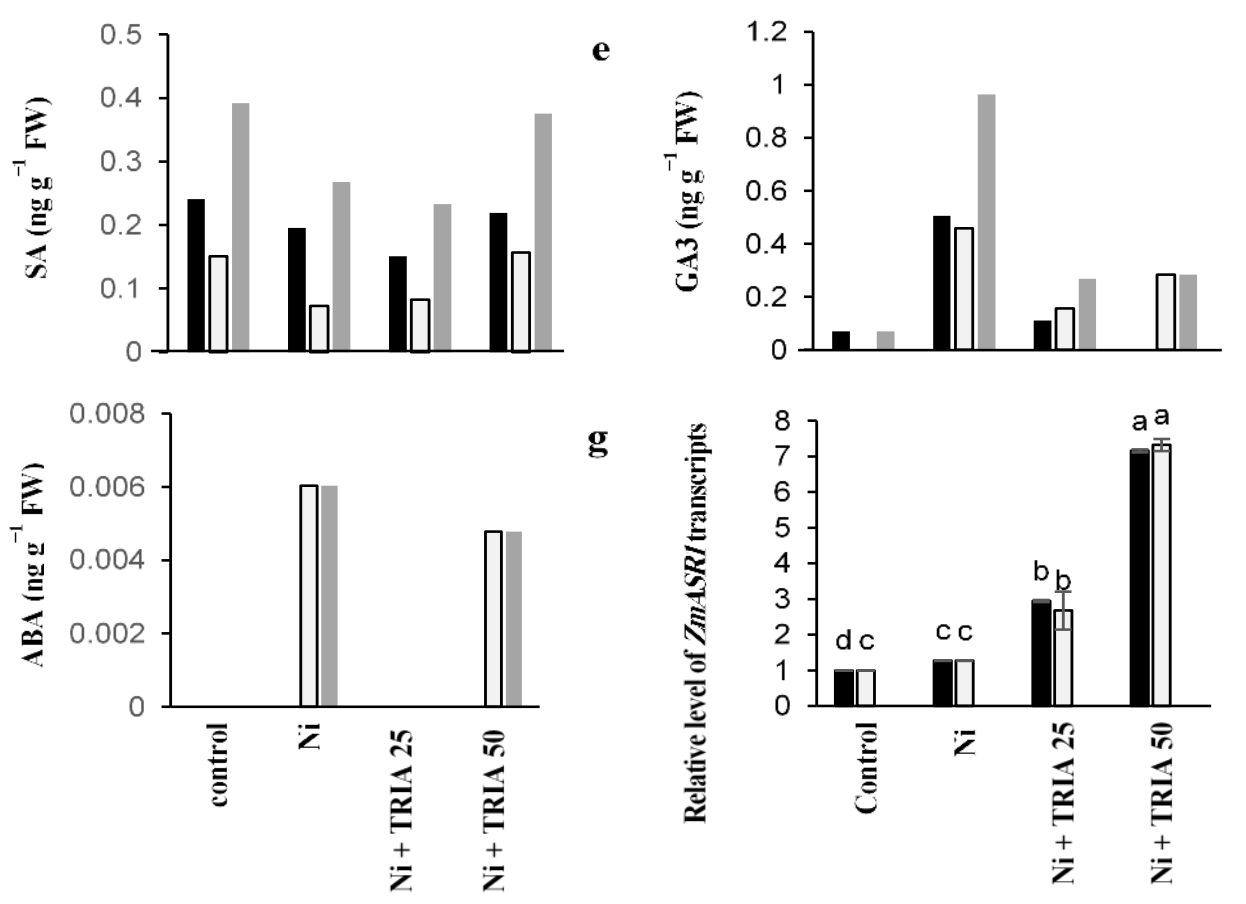

g

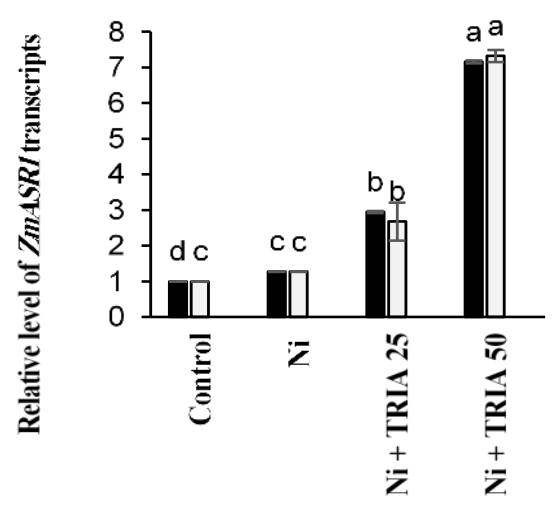

d

h

Fig. 5. Effect of nickel (Ni) alone or combined with different concentrations of triacontanol (TRIA; 25 and 50 $\mu \mathrm{M}$ ) on plant hormones content a) IAA, b) IBA, c) total auxins, d) IAA/IBA ratio e) SA, f) GA3, g) ABA, and $\mathbf{h}$ ) abscisic acid- stress- ripening (ZmASR1) gene expression of maize seedlings. Data of gene expression are means $\pm S D, n=3$, bars with different letters indicate significant differences at $P \leq$ 0.05

Those effects of TRIA on photosynthesis could be presumably attributed to the elevated number and size of chloroplasts, enhanced biosynthesis of chlorophyll, and enhanced photosystem II activity, which were recorded by Chandra \& Roychoudhury ${ }^{[45]}$ and Ramos-Zambrano et al [46]. TRIA has also been reported to hamper chlorophyllase activity, modulate the fluidity of chloroplast membrane and its associated bound enzymes, and enhance the progression of thylakoid grana ${ }^{[47]}$. 
Relative Water Content (RWC) is an important determinant of a plant's growth under environmental stresses ${ }^{[48]}$. In this study, Ni reduced the RWC of the shoot and to a higher extent of the root of maize seedling. Reduced root length and small leaf area obtained in the present work are possible reasons for the lower RWC of maize seedlings. TRIA treatment caused a slight retrieval of shoot RWC, which is probably induced by modulating photosynthesis and membrane fluidity ${ }^{[47]}$. The elevated percentage of EL of $\mathrm{Ni}$-stressed shoots and roots, recorded in this work, is a direct indicator of membrane damage and lipid peroxidation of cell membranes ${ }^{[43,49]}$, and might also be a result of impaired activity of the plasma membrane transporters ${ }^{[50]}$. TRIA application mitigated the $\mathrm{Ni}$ effect on the EL of both maize shoots and roots, which agrees with the results obtained by Ali and Perveen ${ }^{[41]}$ and Nabi et al. ${ }^{[17]}$ who reported similar ameliorative effects of TRIA on membranes' stability under HMs. TRIA may execute these effects via altered fatty acid composition and lipid-protein interaction of cellular membranes ${ }^{[47] .}$

In the current study, the proline content of both shoots and roots was not affected by Ni stress, however, the TSS content of maize shoots has been significantly decreased by Ni treatment, which agrees with the adverse impact of HMs on sugar metabolism in plants [51]. HMs-induced oxidative stress might alter primary carbohydrate metabolism and change sugar source-sink partitioning which eventually inhibits plant growth ${ }^{[52]}$. On the other hand, the maximum value of proline content was recorded in $\mathrm{Ni}$-stressed maize shoots treated with TRIA $(50 \mu \mathrm{M})$ that exceeded even the control level at the expense of TSS content as the proline biosynthesis is an energy-demanding process ${ }^{[53]}$. These results suggest that TRIA treatment favors proline accumulation in the shoot to protect the photosynthetic apparatus which is the most important machinery in the plant ${ }^{[38]}$. This was confirmed by the significant positive correlation $(P<0.01)$ between the proline content of shoots and all photosynthetic pigments.

In the current work, maize plants exposed to $100 \mathrm{mM}$

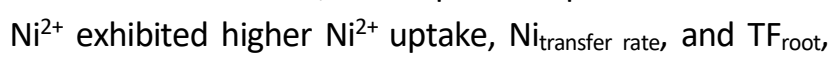
which was probably related to the immobilization of $\mathrm{Ni}^{2+}$ ions in the root cortex and its chelation to organic acids in root tissues as a potential tolerance mechanism ${ }^{[54]}$.
$\mathrm{Ni}^{2+}$ localizationin the roots recorded in the present investigation might be an adaptive response of plants to prevent the transport of toxic amounts of $\mathrm{Ni}$ to the photosynthetic tissues ${ }^{[55]}$. TRIA application to $\mathrm{Ni}$ treated plants led to lower $\mathrm{Ni}_{\text {plant }}$ uptake, and $\mathrm{TF}_{\text {root }}$ in a concentration-dependent manner, implying that TRIA might block the entrance of $\mathrm{Ni}$ to the plant, mainly into roots. This might be related to the TRIA lipophilic nature that may enable its interaction with cellular membranes affecting its permeability for heavy metals ${ }^{[47]}$. Ni fixation in the cell wall, subcellular compartmentalization in roots, and its chelation and sequestration in vacuoles are all potential mechanisms of Ni detoxification ${ }^{[56]}$.

$\mathrm{Ni}^{2+}$ stress triggered a reduction in $\mathrm{K}^{+}, \mathrm{Mg}^{2+}, \mathrm{Ca}^{2+}$, $\mathrm{Mn}^{2+}$ and $\mathrm{Fe}^{2+}$ levels in both roots and whole seedlings of maize. Those essential nutrients participate in many physiological and biochemical processes in plants ${ }^{[57]}$. Decreased $\mathrm{K}^{+}$content under $\mathrm{Ni}$ stress may be due to $\mathrm{K}^{+}$ efflux through potassium outward rectifying channels activated by hydroxyl radicals produced by HMs ${ }^{[58]}$. Further, Ni stress can inhibit ZIP/NRAMP root transporters linked to the uptake of other divalent cations, such as $\mathrm{Ca}^{2+}, \mathrm{Mg}^{2+}, \mathrm{Fe}^{2+}$, and $\mathrm{Zn}^{2+}[59,60]$. Additionally, $\mathrm{Ni}$ was reported to compete with $\mathrm{Mg}^{2+}$, $\mathrm{Fe}^{2+}$, and $\mathrm{Zn}^{2+}$ (of similar ion size) at their transporters ${ }^{[38]}$. On the other hand, enhanced contents of $\mathrm{K}^{+}, \mathrm{Mg}^{2+}$ and $\mathrm{Ca}^{2+}$ in $\mathrm{Ni}^{2+}$-stressed maize shoot observed in this work may be explained by their enhanced loading in the shoot as a technique to maintain the photosynthetic process under stress, though the whole seedling content of these ions was less than that of the control ${ }^{[61]}$. Our data showed a similar pattern of $\mathrm{Ni}$ uptake and $\mathrm{Ca}^{2+}$ content in shoots of maize seedlings, which might be explained as a strategy for sequestration of $\mathrm{Ni}$, as heavy metals were found to be chelated in leaves of some plants in the form of Ca oxalate crystals ${ }^{[62]}$. In the present work, treatment of Ni-stressed maize seedling with either concentration of TRIA managed to replenish the contents of $\mathrm{K}^{+}, \mathrm{Mg}^{2+}$ and $\mathrm{Ca}^{2+}$ in roots and the whole seedling, whereas $\mathrm{Fe}^{2+}$ content in shoots and the whole plant was increased by treatment with $25 \mu \mathrm{M}$ TRIA. A comparable ameliorative effect of TRIA on mineral nutrition balance was documented by Romero-Martínez et al. ${ }^{[47]}$. 
Our data showed that $\mathrm{Ni}$-stressed roots accumulated IAA meanwhile it contained low levels of IBA compared with the control. On the other hand, Ni stress reduced the contents of IAA, IBA, and total auxins of shoots. Our results suggest that $\mathrm{Ni}$ stress activated IBA conversion to IAA in roots as well as IAA basipetal transport as compensation for the stunted growth, which was supported by the work of Frick and Strader [63]. The effect of TRIA on auxins metabolism, transport, conjugation, and signaling is under investigation, yet our results showed that TRIA increased IAA content in roots, while it reduced its accumulation in shoots of $\mathrm{Ni}$ stressed seedlings. Those results corresponded with the fully revived RTI and partially restored STI of TRIAtreated plants. Moreover, Soundararajan et al. [64] reported simultaneous enhancement of both IAA content and root emergence upon TRIA treatment of tomato in vitro cultures,annotating its role in enhanced root growth. Our results revealed that both shoots and roots of $\mathrm{Ni}$-stressed seedlings exhibited a reduced level of SA compared with the unstressed control, which might be supported by the findings of Freeman et al. ${ }^{[65]}$, who reported blocked SA signaling by $\mathrm{Ni}$ stress. TRIA application $(50 \mu \mathrm{M})$ restored SA levels in both shoots and roots to comparable levels of the control plants. SA is known to repress heavy metals absorption, repair the stress-induced photosynthetic impairment, regulate ROS scavenging, and prevent membrane damage by HMs ${ }^{[66]}$. The ability of plants to adapt to HMs was found to be related to the low contents of $\mathrm{GA}_{3}$, while higher concentrations of $\mathrm{GA}_{3}$ were related to increased oxidative damage caused by HMs ${ }^{[66]}$. Similarly, in this work, elevated levels of $\mathrm{GA}_{3}$ were detected in shoots and roots of Ni-exposed maize seedlings accompanied by membrane damage that was displayed as a high level of EL\%. Ni-induced accumulation of ABA together with the reduced RWC, recorded in this work, supported the potential involvement of $A B A$ in the inhibition of $\mathrm{Ni}$ translocation through the xylem stream to the shoots ${ }^{[67]}$.ABA was reported to stimulate metallothioneins (metal-binding protein responsible for HM sequestration in roots) expression in roots under heavy metal stress ${ }^{[68]}$.In the present work, ABA was not detected in $\mathrm{Ni}$-stressed roots treated with the low concentration of TRIA $(25 \mu \mathrm{M})$, but it was retrieved in those treated with $50 \mu \mathrm{M}$ TRIA, which agrees with the comparable findings of El-Shafey et al. ${ }^{[69]}$. On the contrary, Chen et al. ${ }^{\left[{ }^{70]}\right.}$ reported a reduction of $A B A$ content and its related genes in response to TRIA treatment in rice. These contradictory results might be attributed to the complex processes involved in ABA synthesis, perception, and signaling [71]. Additionally, the conditions at which the experiments were conducted, plant species, and growth stage are all factors that must be taken into consideration when dealing with those conflicting results. Given that TRIA treatment, in this work, enhanced the expression of ZmASR1 (a gene involved in $A B A$ signal transduction) in a concentrationdependent manner under Ni stress treatment. Such enhancement of ZmASR1 expression by TRIA treatment may be improved roots tolerance to $\mathrm{Ni}$, which was evidenced by high RTI and reduced level of toxicity in roots found in this study.

\section{CONCLUSION}

In conclusion, $\mathrm{Ni}$ stress reduced the growth and developmental processes of the Zea mays plants. This work confirmed that foliar spray of maize seedlings with TRIA was effective in mitigating the detrimental effects of $\mathrm{Ni}$ on growth and photosynthesis, more so with $50 \mu \mathrm{M}$ TRIA. TRIA-induced photosynthesis recuperation under $\mathrm{Ni}$-stress might be triggered by enhanced photosynthetic pigments, photosynthetic performance, and $Z m R B C S$ expression. This paper aimed to address the interaction between TRIA and both osmolytes and hormonalbalance under Ni stress. Our results showed that TRIA altered osmolyte accumulation, balancing between sugar and proline accumulation in an organ-specific manner, which might be intended for energy-saving purposes. Hormonal balance was greatly transformed by TRIA application (especially $50 \mu \mathrm{M}$ ) under Ni stress, by increasing IAA/ IBA ratio in roots exposed to $\mathrm{Ni}$ and restoring $\mathrm{SA}$ in both shoots and roots. All those changes caused by TRIA ultimately cast on the better exclusion of Ni from maize seedlings, basically from roots. The interconnection between hormonal signaling and ion transporters under TRIA application and its role in alleviating $\mathrm{Ni}$ toxicity will be a prospective point to study. 


\section{ABBREVIATIONS}

ABA: abscisic acid; Car: carotenoids; Chl a: chlorophyll a; Chl b: chlorophyll b; DW: dry weights; EL: electrolyte leakage; FW: fresh weight; $\mathbf{G A}_{3}$ : gibberellic acid; HMs: Heavy metal stress; IAA: indole acetic acid; IBA: indole butyric acid; Ni: nickel; Ni-TI: Ni tolerance index; $\mathrm{Ni}_{\text {transfer }}$ rate: plant $\mathrm{Ni}$ transfer rate; $\mathbf{P I}_{\text {abs: }}$ photosynthetic performance index; $\mathbf{R T I}$ : root tolerance index; Rubisco: Ribulose-1,5-biphosphate carboxylase/oxygenase; RWC: relative water content; SA: salicylic acid; STI: shoot tolerance index; TF root: root transfer factor; TF $_{\text {shoot: shoot transfer }}$ factor; TRIA: triacontanol; TSS: total soluble sugar; ZmASR1: abscisic acid- stress- ripening gene; ZmRBCS: Rubisco small subunit gene.

\section{References}

1. Shaheen, S. M., Abdelrazek, M. A. S., Elthoth, M., Moghanm, F. S., Mohamed, R., Hamza, A., El-Habashi, N., Wang, J. and Rinklebe, J. (2019). Potentially toxic elements in saltmarsh sediments and common reed (Phragmites australis) of Burullus coastal lagoon at North Nile Delta, Egypt: a survey and risk assessment. Sci. Total Environ., 649: 1237 1249.

2. El-Alfy, M. A., El-Amier, Y. A. and El-Eraky, T. E. (2020). Land use/cover and eco-toxicity indices for identifying metal contamination in sediments of drains, Manzala Lake, Egypt. Heliyon., 6: e03177.

3. Kabata-Pendias, A. and Mukherjee, A. B. (2007). Trace elements from soil to human. Springer Science \& Business Media.

4. Czajka, K. M., Michael, P. and Nkongolo, K. (2019). Differential effects of nickel dosages on in vitro and in vivo seed germination and expression of a high affinity nickel-transport family protein (AT2G16800) in trembling aspen (Populus tremuloides). Ecotoxicology, 28: $92-102$.

5. Moreira, I. N., Martins, L. L. and Mourato, M. P. (2020). Effect of $\mathrm{Cd}, \mathrm{Cr}, \mathrm{Cu}, \mathrm{Mn}, \mathrm{Ni}, \mathrm{Pb}$ and $\mathrm{Zn}$ on seed germination and seedling growth of two lettuce cultivars (Lactuca sativa L.). Plant Physiol. Reports, 25: 347 - 358.
6. Seregin, I. V. and Kozhevnikova, A. D. (2006). Physiological role of nickel and its toxic effects on higher plants. Russ. J. Plant Physiol., 53: 257 - 277.

7. Llamas, A., Ullrich, Cl. and Sanz, A. (2008). $\mathrm{Ni}^{2+}$ toxicity in rice: effect on membrane functionality and plant water content. Plant Physiol. Biochem., 46: 905 - 910 .

8. Rucińska-Sobkowiak, R. (2016). Water relations in plants subjected to heavy metal stresses. Acta Physiol. Plant, 38: 1 - 13.

9. Hassan, M. U., Chattha, M. U., Khan, I., Chattha, M. B., Aamer, M., Nawaz, M., Ali, A., Khan, M. A. U. and Khan, T. A. (2019). Nickel toxicity in plants: reasons, toxic effects, tolerance mechanisms, and remediation possibilities-a review. Environ. Sci. Pollut. Res., 26: 12673 12688.

10. FAOSTAT (2020). Crop Yields.

11. Okereafor, U., Makhatha, M., Mekuto, L., UcheOkereafor, N., Sebola, T. and Mavumengwana, V. (2020). Toxic metal implications on agricultural soils, plants, animals, aquatic life and human health. Int. J. Environ. Res. Public Health, 17: 2204.

12. Hasanuzzaman, M., Nahar, K,. Alam, M. M., Roychowdhury, R. and Fujita, M. (2013). Physiological, biochemical, and molecular mechanisms of heat stress tolerance in plants. Int. J. Mol. Sci., 14: 9643 - 9684.

13. Chen, X., Yuan, H., Chen, R., Zhu, L. and He, G. (2003). Biochemical and photochemical changes in response to triacontanol in rice (Oryza saliva L.). Plant Growth Regul., 40: 249 - 256.

14. Ertani, A., Schiavon, M., Muscolo, A. and Nardi, S. (2013). Alfalfa plant-derived biostimulant stimulate short-term growth of salt stressed Zea mays L. plants. Plant Soil, 364: 145- 158.

15. Chen, X., Goodwi,n S. M., Liu, X., Chen, X., Bressan, R. A. and Jenks, M. A. (2005). Mutation of the resurrection1 locus of Arabidopsis reveals an association of cuticular wax with embryo development. Plant Physiol., 139: 909 - 919.

16. Naeem, M., Khan, M. M. A. and Moinuddin, (2012). Triacontanol: a potent plant growth regulator in agriculture. J. Plant Interact., 7: 129 142. 
17. Nabi, A., Parwez, R., Aftab, T., Khan, M. M. A. and Naeem, M. (2020). Triacontanol Protects Mentha arvensis L. from Nickel-Instigated Repercussions by Escalating Antioxidant Machinery, Photosynthetic Efficiency and Maintaining Leaf Ultrastructure and Root Morphology. J. Plant Growth Regul., 1-19.

18. Heba, M. H. (2013). The potential role of triacontanol in certain physiological aspects of Zea mays L. single cross Giza 310 grown under normal and environmental stress conditions. PhD., Fac. Sci. Ain Shams Univ.

19. Perveen, S., Shahbaz, M. and Ashraf, M. (2014). Triacontanol-induced changes in growth, yield, leaf water relations, oxidative defense system, minerals, and some key osmoprotectants in Triticum aestivum under saline conditions. Turk. J. Botany, 38: 896 913.

20. Islam, S., Zaidm A. and Mohammad, F. (2020). Role of Triacontanol in Counteracting the III Effects of Salinity in Plants: A Review. J. Plant Growth Regul., 40: 1 - 10.

21. Smith, G. S., Johnston, C. M. and Cornforth, I. S. (1983). comparison of nutrient solutions for growth of plants in sand culture. New Phytol., 94: $537-548$.

22. Valivand, M., Amooaghaie, R. and Ahadi, A. (2019). Seed priming with $\mathrm{H}_{2} \mathrm{~S}$ and $\mathrm{Ca}^{2+}$ trigger signal memory that induces cross-adaptation against nickel stress in zucchini seedlings. Plant Physiol. Biochem., 143: 286 - 298.

23. Alam, P., Kaur Kohli, S., Al Balawi, T., Altalayan, F. H., Alam, P., Ashraf, M., Bhardwaj, R. and Ahmad, P. (2020). Foliar application of 24-Epibrassinolide improves growth, ascorbate-glutathione cycle, and glyoxalase system in brown mustard (Brassica juncea (L.) Czern.) under cadmium toxicity. Plants, 9: 1487.

24. Amooaghaie, R., Tabatabaei, F. and Ahadi, A. (2015). Role of hematin and sodium nitroprusside in regulating Brassica nigra seed germination under nanosilver and silver nitrate stresses. Ecotoxicol. Environ. Saf. 113: $259-270$.
25. Bálint, A. F., Kovács, G. and Sutka, J. (2002). Copper tolerance of Aegilops, Triticum, Secale and triticale seedlings and copper and iron content in their shoots. Acta. Biol. Szeged., 46: $77-78$.

26. Maxwell, K. and Johnson, G. N. (2000). Chlorophyll fluorescence-a practical guide. J. Exp. Bot., 51: $659-668$.

27. Metzner, H., Rau, H. and Senger, H. (1965). Untersuchungen zur Synchronisierbarkeit einzelner Pigmentmangel-Mutanten von Chlorella. Planta, 65: $186-194$.

28. Livak, K. J. and Schmittgen, T. D. (2001). Analysis of relative gene expression data using real-time quantitative $P C R$ and the 2- $\triangle \Delta C T$ method. Methods, 25: $402-408$.

29. Pan, Y., Seymour, G. B., Lu, C., Hu, Z., Chen, X. and Chen, G. (2012). An ethylene response factor (ERF5) promoting adaptation to drought and salt tolerance in tomato. Plant Cell Rep., 31: $349-360$.

30. Valentovic, P., Luxova, M., Kolarovic, L. and Gasparikova, O. (2006). Effect of osmotic stress on compatible solutes content, membrane stability and water relations in two maize cultivars. Plant Soil Environ., 52: 184.

31. McCready, R. M., Guggolz, J., Silviera, V. and Owens, H. S. (1950). Determination of Starch and Amylose in Vegetables. Anal. Chem., 22: $1156-1158$.

32. Bates, L. S., Waldren, R. P. and Teare, I. D. (1973). Rapid determination of free proline for water-stress studies. Plant Soil, 39: 205 - 207.

33. Xiong, T., Dumat, C., Dappe, V., Vezin, H., Schreck, E., Shahid, M., Pierart, A. and Sobanska, S. (2017). Copper oxide nanoparticle foliar uptake, phytotoxicity, and consequences for sustainable urban agriculture. Environ. Sci. Technol., 51: $5242-5251$.

34. Abbas, Q., Yousaf, B., Liu, G., Zia-ur-Rehman, M., Ali, M. U., Munir, M. A. M. and Hussain, S. A. (2017). Evaluating the health risks of potentially toxic elements through wheat consumption in multi-industrial metropolis of Faisalabad, Pakistan. Environ. Sci. Pollut. Res., 24: $26646-26657$. 
35. Zaid, A., Mohammad, F., Wani, S. H., Siddique, K. M. H. (2019). Salicylic acid enhances nickel stress tolerance by upregulating antioxidant defense and glyoxalase systems in mustard plants. Ecotoxicol. Environ. Saf. 180: 575 - 587.

36. Aqeel, M., Khalid, N., Tufail, A., Ahmad, R. Z., Akhter, M. S., Luqman, M., Javed, M. T., Irshad, M. K., Alamri, S. and Hashem, M. (2021). Elucidating the distinct interactive impact of cadmium and nickel on growth, photosynthesis, metal-homeostasis, and yield responses of mung bean (Vigna radiata L.) varieties. Environ. Sci. Pollut. Res., 1 - 15.

37. Bhalerao, S. A., Sharma, A. S. and Poojari, A. C. (2015). Toxicity of nickel in plants. Int. J. Pure Appl. Biosci., 3: 345 - 355.

38. Ahmad, M. S. A. and Ashraf, M. (2012). Essential roles and hazardous effects of nickel in plants. Rev. Environ. Contam. Toxicol., 125 167.

39. Batool, S. (2018). Effect of nickel toxicity on growth, photosynthetic pigments and dry matter yield of Cicer arietinum L. varieties. Asian J. Agri. Biol., 6: 143 - 148.

40. Naeem, M., Ansari, A. A., Aftab, T., Shabbir, A., Alam, M. M., Khan, M. M. A. and Uddin, M. (2019). Application of triacontanol modulates plant growth and physiological activities of Catharanthus roseus (L.). Int. J. Bot. Stud., 4: $131-135$.

41. Ali, H. M. M. and Perveen, S. (2020). Effect of foliar applied triacontanol on wheat (Triticum aestivum L.) under arsenic stress: a study of changes in growth, yield and photosynthetic characteristics. Physiol. Mol. Biol. Plants, 26: $1215-1224$.

42. Khan, Z. H., Mohammad, F. and Khan M. M. A. (2014). Enhancing the growth, yield and production of essential oil and citral in lemongrass by the application of triacontanol. Int. J. Agric. Res., 4: 113-122.

43. Younis, A. A. and Ismail, H. A. (2019). Triacontanol Alleviated Nickel Toxicity in Maize Seedling by Controlling Its Uptake and Enhancing Antioxidant System. J. Adv. Plant Biol., 1: 1-15.
44. Hussain, M. B., Ali, S., Azam, A., Hina, S., Farooq, M. A., Ali, B., Bharwana, S. A. and Gill, M. B. (2013). Morphological, physiological and biochemical responses of plants to nickel stress: A review. African J. Agric. Res., 8: 1596 -1602 .

45. Chandra, S. and Roychoudhury, A. (2020). Penconazole, Paclobutrazol, and Triacontanol in Overcoming Environmental Stress in Plants. Prot. Chem. Agents Amelior. Plant Abiotic Stress Biochem. Mol. Perspect, 510 - 534.

46. Ramos-Zambrano, E., Juárez-Yáñez, T. E., Tapia-Maruri, D., Camacho-Díaz, B. H., Jiménez-Aparicio, A. R. and Martínez-Ayala, A. L. (2020). Effects of Triacontanol and Light on Stomatal and Photochemical Responses in Solanum lycopersicum L. J. Plant Growth Regul., 1 - 13 .

47. Romero-Martínez, N., Ramos-Zambrano, E., Osorio-Ruiz, A. and Martínez-Ayala, A. L. (2021). Main Mechanisms of Action of Policosanol in Animal and Plant Cells. Int. J. Pharm. Res. Allied Sci., 10(2): $10-20$.

48. Onyekachi, O. G., Boniface, O. O., Gemlack, N. F. and Nicholas, N. (2019). The effect of climate change on abiotic plant stress: a review. Abiotic Biot. Stress Plants.

49. Gajewska, E., Niewiadomska, E., Tokarz, K., Słaba, M. and Skłodowska, M. (2013). Nickelinduced changes in carbon metabolism in wheat shoots. J. Plant Physiol., 170: $369-377$.

50. Nazir, F., Hussain, A. and Fariduddin, Q. (2019). Interactive role of epibrassinolide and hydrogen peroxide in regulating stomatal physiology, root morphology, photosynthetic and growth traits in Solanum lycopersicum L. under nickel stress. Env. Exp. Bot., 162: 479 495.

51. Rosa, M., Prado, C., Podazza, G., Interdonato, R., González, J. A., Hilal, M. and Prado, F. E. (2009). Soluble sugars: Metabolism, sensing and abiotic stress: A complex network in the life of plants. Plant Signal Behav., 4: 388 - 393.

52. Gill, M. (2014). Heavy metal stress in plants: a review. Int. J. Adv. Res., 2: 1043 - 1055. 
53. Zhang, L. and Becker, D. (2015). Connecting proline metabolism and signaling pathways in plant senescence. Front Plant Sci., 6: 552.

54. Page, V. and Feller, U. (2015). Heavy metals in crop plants: Transport and redistribution processes on the whole plant level. Agronomy, 5: $447-463$.

55. Mallick, S., Sinam, G., Mishra, R. K. and Sinha, S. (2010). Interactive effects of $\mathrm{Cr}$ and $\mathrm{Fe}$ treatments on plants growth, nutrition and oxidative status in Zea mays L. Ecotoxicol. Environ. Saf., 73: 987 - 995.

56. Shahzad, B., Tanveer, M., Rehman, A., Cheema, S. A., Fahad, S., Rehman, S. and Sharma, A. (2018). Nickel; whether toxic or essential for plants and environment-A review. Plant Physiol. Biochem., 132: 641 651.

57. White, P. J. and Brown, P. H. (2010). Plant nutrition for sustainable development and global health. Ann. Bot., 105: 1073 - 1080.

58. Palm, E., Nissim, W. G., Giordano, C., Mancuso, S. and Azzarello, E. (2017). Root potassium and hydrogen flux rates as potential indicators of plant response to zinc, copper and nickel stress. Environ. Exp. Bot., 143: 38 - 50 .

59. Asha, S. and Anju, D. (2013). Nickel and cadmium toxicity in plants. J. Pharm. Sci. Innov., 2: 20 - 24.

60. Deng, T. (2016). Nickel uptake and transport in the hyperaccumulator Noccaea Caerulescens.

61. Hasanuzzaman, M., Bhuyan, M. H. M., Nahar, K., Hossain, M., Mahmud, J. Al., Hossen, M., Masud, A. A. C. and Fujita, M. (2018). Potassium: a vital regulator of plant responses and tolerance to abiotic stresses. Agronomy, 8: 31.

62. Osmolovskaya, N., Dung, V. V. and Kuchaeva, L. (2018) The role of organic acids in heavy metal tolerance in plants. Biol. Commun., 63(1): 9-16.

63. Frick, E. M. and Strader, L. C. (2018). Roles for IBA-derived auxin in plant development. J. Exp. Bot., 69: $169-177$.
64. Soundararajan, M., Swamy, G. S., Gaonkar, S. K. and Deshmukh, S. (2018). Influence of triacontanol and jasmonic acid on metabolomics during early stages of root induction in cultured tissue of tomato (Lycopersicon esculentum). Plant Cell, Tissue Organ Cult., 133: 147 - 157.

65. Freeman, J. L., Garcia, D., Kim, D., Hopf, A. and Salt, D. E. (2005). Constitutively elevated salicylic acid signals glutathione-mediated nickel tolerance in Thlaspi nickel hyperaccumulators. Plant Physiol., 137: 1082 1091.

66. Saini, S., Kaur, N. and Pati, P. K. (2021). Phytohormones: Key players in the modulation of heavy metal stress tolerance in plants. Ecotoxicol. Environ. Saf. 223: 112578.

67. Bücker-Neto, L., Paiva, A. L. S., Machado, R. D., Arenhart, R. A. and Margis-Pinheiro, M. (2017). Interactions between plant hormones and heavy metals responses. Genet. Mol. Biol., 40: 373 - 386.

68. Leszczyszyn, O. I., Imam, H. T. and Blindauer, C. A. (2013). Diversity and distribution of plant metallothioneins: a review of structure, properties and functions. Metallomics, 5: 1146 - 1169.

69. El-Shafey, S. A., Hassan, H. M. and Ahmad, H. F. S. (2018). Involvement of Triacontanol in Regulation of Seed Germination and Seedling Growth of Zea mays L. J. Exp. Biol., 14: $375-383$.

70. Chen, X., Yuan, H., Chen, R., Zhu, L., Du, B. and Weng, Q. He. G. (2002). Isolation and Characterization of Triacontanol-Regulated Genes in Rice (Oryza sativa L.): Possible Role of Triacontanol as a Plant Growth Stimulator. Plant Cell Physiol., 43: $869-876$.

71. Rehman, A., Azhar, M. T., Hinze, L., Qayyum, A., Li, H., Peng, Z., Qin, G., Jia, Y., Pan, Z. and He, S. (2021). Insight into abscisic acid perception and signaling to increase plant tolerance to abiotic stress. J. Plant Interact., 16: $222-237$. 